\title{
Aqueous extract of Azadirachta indica leaves favorably alters the course of streptozotocin-induced diabetes in rats: A comparative prospective cohort study
}

\author{
Obiajulu C. Ezeigwe ${ }^{1,{ }^{*}}$, Francis C. Ezeonu ${ }^{1}$, Chukwudi O. Okani ${ }^{2}$, Daniel N. Onwusulu ${ }^{3}$, Maryclare E. Onuegbu ${ }^{1}$
}

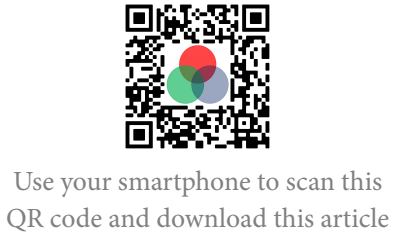

${ }^{1}$ Department of Applied Biochemistry, Faculty of Biosciences, Nnamdi Azikiwe University, Awka, Anambra State, Nigeria

${ }^{2}$ Department of Histopathology, Chukwuemeka Odumegwu Ojukwu University, Awka Campus, Anambra State, Nigeria

${ }^{3}$ Department of Obstetrics and Gynaecology, Faculty of Medicine, College of Health Sciences, Nnamdi Azikiwe University, Nnewi Campus, Anambra State, Nigeria

\section{Correspondence}

Obiajulu C. Ezeigwe, Department of Applied Biochemistry, Faculty of Biosciences, Nnamdi Azikiwe University, Awka, Anambra State, Nigeria

Email: oc.ezeigwe@unizik.edu.ng

\section{History}

- Received: May 11, 2020

- Accepted: Jul 25, 2020

- Published: Jul 31, 2020

DOI : 10.15419/bmrat.v7i7.617

\section{Check for updates}

Copyright

(C) Biomedpress. This is an openaccess article distributed under the terms of the Creative Commons Attribution 4.0 International license.

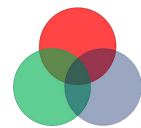

\begin{abstract}
Introduction: Azadirachta indica (neem) is one of the plants commonly used in African traditional medicine for the treatment and management of diabetes mellitus. The present study was undertaken to evaluate the effect of aqueous extract of $A$. indica leaves on hematology, lipid profile and organ-system function of streptozotocin-induced diabetic male rats. Methods: Thirty albino rats of Wistar strain, weighing between 120 and $150 \mathrm{~g}$, were randomly divided into 6 groups (A-F) and used for the study. Group A was used as a healthy normal control. Groups B-F were induced with diabetes using $50 \mathrm{mg} / \mathrm{kg}$ bodyweight (bw.) of streptozotocin. Group B was diabetic untreated; Group C was treated with $100 \mathrm{mg} / \mathrm{kg}$ bw. metformin; Groups D to F were treated with 100, 200 and $400 \mathrm{mg} / \mathrm{kg}$ bw. of the aqueous extract, respectively. The treatment was carried out daily for a period of 28 days. At the end of the experimental period, the hematological parameters were analyzed using auto haematology analyser. Lipid profiles and histopathological investigations were performed using standard methods. Results: The results obtained showed that aqueous extract of A. indica significantly $(p<0.05)$ increased the hemoglobin concentration, packed cell volume, red blood cell count, and platelet count of the streptozotocin-induced diabetic rats compared with those of the diabetic-untreated rats. The mean hemoglobin concentrations for groups A, B, C, D, E and F were $11.78,8.200,15.18,13.88,14.03$ and 14.93, respectively. Treatment with the graded doses of the aqueous extract of $A$. indica significantly $(p<0.05)$ reduced the total cholesterol, low-density lipoprotein cholesterol, triglycerides and very-low-density lipoprotein, compared with those of the diabetic-untreated control. Treatment also significantly $(p<0.05)$ increased the high-density lipoprotein cholesterol $(\mathrm{HDL}-\mathrm{c})$, compared with that of the control. The mean $\mathrm{HDL}-\mathrm{C}$ concentration for groups A, B, C, D, E and F were 49.58, 29.79, 40.89, 38.53, 40.40 and 46.54, respectively. The histopathological studies showed regeneration of the pancreas, liver, kidney, heart, brain and lungs for the groups treated with the extract, compared with the diabetic-untreated animals that revealed severe damage to the organ-system functions. Conclusion: These results suggest that the aqueous extract of $A$. indica can be considered as an excellent remedy for diabetes and a substitute for drugs to reduce complications associated with diabetic conditions.

Key words: Azadirachta indica, diabetes, streptozotocin, haemoglobin, total cholesterol, pancreas
\end{abstract}

\section{INTRODUCTION}

Diabetes mellitus is a chronic heterogeneous disorder of carbohydrate metabolism that occurs either when the pancreas does not produce enough insulin or when the body cannot use the insulin it produces effectively. It is characterized by hyperglycemia, frequent urination, dehydration, weight gain or loss, and frequent hunger. The most known types of diabetes are type 1 (insulin-dependent diabetes mellitus), type 2 (non-insulin dependent diabetes mellitus), and gestational diabetes mellitus. Type 2 diabetes is considered to be the most prevalent and a result of resistance to insulin action ${ }^{1}$. Diabetes can cause complications such as cardiovascular disease, neuropathy, high blood pressure, weakness, gangrene, retinopa- thy, nephropathy and other dysfunctions, leading to increase in the overall risk of mortality in diabetic patients ${ }^{2}$. Other complications include high blood pressure, heart complications, stroke, leg amputation, kidney failure, loss of vision and nerve damage. In pregnancy, poorly controlled diabetes can increase the risk of fetal death as well as other complications ${ }^{3}$.

Considering statistics by the World Health Organization (WHO), diabetes has shown a remarkable increase in predominance with a demographic transition in its epidemiology in recent years. It affects both young and old in the general public. Globally, an estimated 422 million adults were living with diabetes in 2014, compared to 108 million in $1980^{3}$. In 2017, it was estimated that 425 million people (20 -79 years of 
age) suffered from DM, and the number is expected to rise to 629 million by $2045^{4}$. The IDF Diabetes Atlas 6th Edition shows that Nigeria is the leading country in Africa in terms of the number of people with diabetes, with 3.9 million cases of diabetes and 105,091 diabetes-related deaths in 2013; this has been estimated to increase annually by 125,000 between 2010 and 2030. In addition, there are still about 1.8 million Nigerians with undiagnosed diabetes in $2013^{5}$.

The high cost of conventional drugs used for the treatment of diabetes and its concomitant side effects have impeded the treatment and management of diabetes mellitus in contemporary times. Also, none of the antidiabetic drugs could give long-term glycemic control. Presently, there is a keen interest in alternative medicine which will have minimal or no side effects and at the same time be affordable to the common man in the society. Currently, medicinal plants that are effective in controlling fasting blood glucose levels with minimal side effects are commonly used in underdeveloped countries as alternative therapy, although the mechanism of these herbal remedies is yet to be entirely ascertained scientifically.

In Africa, hundreds of plants are used traditionally for the management and control of diabetes mellitus. Unfortunately, only a few of such medicinal plants have been scientifically validated. One of the plants commonly used in African traditional medicine for the management of diabetes mellitus is Azadirachta indica (Family: Meliaceae), popularly known as "A. indica". It is a medicinal plant grown originally in India but is now being cultivated in almost every part of the world, including Nigeria, where it is called "dogonyaro". It is one of the most useful medicinal plants. The plant contains different alkaloids which include nimbin, azadirachtin and salannin, whose effects contribute individually to the general medicinal properties of the plant ${ }^{6}$. Different parts of this plant have been reported to have antiseptic activity, wound healing activity ${ }^{7}$, and skin disease curing activity ${ }^{8}$. Apart from these uses, there are many reports on the biological activities and pharmacological actions of $A$. indica based on recent scientific investigations.

Some research studies have reported significant blood sugar-lowering effects of $A$. indica in streptozotocininduced diabetic rats ${ }^{9-11}$. It has also been welldocumented that cardiovascular disease induced by hyperglycemia is associated with alterations in serum lipid profiles ${ }^{12,13}$. In our previous studies, we have determined the effects of aqueous extract of $A$. indica leaves on fasting blood glucose concentrations and insulin levels ${ }^{14,15}$. There are a few studies regarding the effects of diabetes on organ weight and organ-system function of experimental animals ${ }^{16,17}$. In this study, we investigated the effects of the aqueous extract of A. indica leaves on hematological parameters, lipid profile and organ-system functions of streptozotocininduced diabetic male rats. Although there are reports on the anti-diabetic effect of the aqueous extract of $A$. indica leaves, this was one of the few research studies that, in addition, examined the effect of the administration of the extract on the body weight, organ weight and histology of the key organs (liver, kidney, heart, lungs, pancreas and brain) affected in diabetes.

\section{MATERIALS AND METHODS}

\section{Collection and Identification of Plant Mate- rials}

The leaves of $A$. indica were collected from Nnamdi Azikiwe University, Awka, Anambra State, Nigeria. The sample was identified by a botanist in the Department of Botany, Nnamdi Azikiwe University, Awka. The voucher number as deposited in the herbarium of Nnamdi Azikiwe University, Awka was 14.

\section{Preparation of Extract}

The leaves were washed and air-dried at room temperature. The dried leaves were pulverized into powder using Corona manual grinding machine. Exactly $1 \mathrm{~kg}$ of the ground leaf powder of $A$. indica was soaked in 5 litres of distilled water for $24 \mathrm{hrs}$ for aqueous extraction. The aqueous extraction was sieved using muslin cloth and filtered using Whatman filter paper. The filtrate was lyophilized (freeze-dried) to powder. The extract was stoppered in universal bottles and preserved in the refrigerator for use. The extract was solubilized with distilled water on a daily basis and administered to the experimental animals (extracttreated groups) for a period of 28 days.

\section{Chemicals}

Streptozotocin was obtained from Sigma Aldrich (Germany). All other chemicals used in this study were of analytical grade.

\section{Experimental Animals}

A total of thirty (30) male albino rats of Wistar strain were bred within the animal house of the Chris Experimental Farm and Research Laboratory, Awka. They were maintained and housed in cages under standard environmental conditions $\left(27^{0} \mathrm{C} \pm\right.$ $3^{0} \mathrm{C}, 12$-hour light/dark cycle) in the Department of Applied Biochemistry Laboratory, Faculty of Biosciences, Nnamdi Azikiwe University, Awka. They were allowed to acclimatize with the environment 
freely for one week before use. The animals were allowed free access to guinea growers mash pellets (Vital feed, Agro products) and water ad libitum.

\section{Animal Grouping and Extract Administra- tion}

Thirty albino rats of Wistar strain weighing between 120 and $150 \mathrm{~g}$ were randomly divided into six groups (Groups A-F). Group A was left uninduced, while Groups B to $\mathrm{F}$ were induced with diabetes intraperitoneally using $50 \mathrm{mg} / \mathrm{kg}$ body weight (bw.) of streptozotocin. Group B was diabetic untreated; Group C was treated with $100 \mathrm{mg} / \mathrm{kg}$ bw. metformin (a standard anti-diabetic drug used for the treatment of diabetes); Group D, E and F were treated with 100, 200 and $400 \mathrm{mg} / \mathrm{kg}$ bw. of the extract, respectively. The treatment was carried out daily for 28 days. After 28 days of treatment, the animals were sacrificed and blood collected by cardiac puncture for hematological and lipid profile analysis. Organs were also harvested and the weights recorded before use in histological analyses.

\section{Determination of Body and Organ Weight}

The bodyweight of the rats and their organs (liver, kidney, heart, lungs, pancreas and brain) were determined using a compact electronic scale (Alpha-SRS 130, China).

\section{Hematological Analysis}

Hematological parameters that were analyzed include Red Blood Cells (RBC), White Blood Cells (WBC), Hemoglobin ( $\mathrm{Hb})$, Packed Cell Volume (PCV) and Platelets. They were determined using an automated hematology analyzer (Mindray BC-2800, China).

\section{Lipid Profile}

The lipid profile [Total Cholesterol (TCH), Triglycerides (TG), High-Density Lipoprotein-Cholesterol (HDL-c), Low-Density Lipoprotein-Cholesterol (LDL-c), and Very Low-Density LipoproteinCholesterol (VLDL-c)] were determined using Randox test kits ${ }^{18,19}$. LDL-c was calculated using a standard formula ${ }^{20}$. The procedure used was according to the manufacturer's instructions.

\section{Histopathological Studies}

Immediately after the animals were sacrificed, the organs were eviscerated and fixed in $10 \%$ buffered formalin. The tissues were grossed and processed after 48 hours of fixation. Tissue procession involved the following dehydration using graded alcohol concentration (starting with $70 \%$ alcohol, to $80 \%$, to $90 \%$ alcohol and 95\% alcohol, and finally with absolute alcohol). The clearing was done with xylene, and Molten paraffin wax was used for infiltration and embedding. Microtomy was done and the slides were stained using Hematoxylin and Eosin method ${ }^{21}$.

\section{Data Analysis}

Data obtained from the experiments were analyzed using the Statistical Package for Social Sciences (SPSS) software for windows version 21 (SPSS Inc., Chicago, Illinois, USA). The data were expressed as Mean \pm SD. Statistical analysis of the continuous variables for the six groups was performed by using Analysis of Variance (ANOVA) to determine if significant difference exists between the mean of the test and control groups. The limit of significance was set at $p<0.05$.

\section{RESULTS}

\section{Result of the bodyweight}

Induction of diabetes caused a significant $(p<0.05)$ reduction in the bodyweight of all the diabetic groups. The mean $( \pm S D)$ of the initial bodyweight of the normal rats, untreated-diabetic, $100 \mathrm{mg} / \mathrm{kg}$ metformintreated, $100 \mathrm{mg} / \mathrm{kg}$ aqueous extract-treated, 200 $\mathrm{mg} / \mathrm{kg}$ aqueous extract-treated and $400 \mathrm{mg} / \mathrm{kg}$ aqueous extract-treated rats before induction of diabetes were 137.4 ( \pm 0.894$), 136.8$ ( \pm 1.789$), 133.6( \pm$ 2.510), $126.8( \pm 3.114), 126.2( \pm 1.304)$ and 128.2 $( \pm 0.8367)$, respectively. The mean ( \pm SD) of the bodyweight of the rats on day 0 , that is after the induction of diabetes were as follows: for non-induced normal rats it was $141.3( \pm 2.060)$, untreated diabetic was $113.7( \pm 3.03), 100 \mathrm{mg} / \mathrm{kg}$ metformin-treated was $118.3( \pm 4.21), 100 \mathrm{mg} / \mathrm{kg}$ aqueous extract-treated was $115.4( \pm 2.70), 200 \mathrm{mg} / \mathrm{kg}$ aqueous extracttreated was $114.9( \pm 3.03)$ and $400 \mathrm{mg} / \mathrm{kg}$ aqueous extract-treated was $110.8( \pm 5.72)$. It is clear from the results that the induction of diabetes caused a significant $(p<0.05)$ reduction in the bodyweight of the rats compared with the normal rats which were not induced. Within the first week of treatment, there was no significant $(p>0.05)$ increase in the bodyweight of the extract-treated groups compared with the diabetic-untreated group. However, as the period of treatment progressed, there was a significant $(p<$ 0.05 ) increase in the bodyweight of the groups treated with the graded doses of the aqueous extract of $A$. in dica leaf from week 2 to week 4, compared with the diabetic-untreated control (Table 1). The mean $( \pm$ SD) bodyweight of the rats treated with $400 \mathrm{mg} / \mathrm{kg}$ bw. 
after 28 days of treatment was $134.0( \pm 3.8)$ while that of $100 \mathrm{mg} / \mathrm{kg}$ and $200 \mathrm{mg} / \mathrm{kg}$ bw. were $129.0( \pm 2.64)$ and $130.0( \pm 2.60)$, respectively. The group that was treated with $400 \mathrm{mg} / \mathrm{kg}$ bw. showed a better increase in bodyweight compared with the other test groups.

\section{Results of the Organ Weights}

The mean $( \pm S D)$ of the weight of the pancreas for the groups were as follows: normal non-diabetic induced control was $1.316( \pm 0.03)$, untreated diabetic was $0.815( \pm 0.04), 100 \mathrm{mg} / \mathrm{kg}$ metformin-treated was $1.114( \pm 0.05), 100 \mathrm{mg} / \mathrm{kg}$ aqueous extract-treated was 1.147 ( \pm 0.08$), 200 \mathrm{mg} / \mathrm{kg}$ aqueous extracttreated was $1.103( \pm 0.01)$ and $400 \mathrm{mg} / \mathrm{kg}$ bw. aqueous extract-treated rats was $1.178( \pm 0.01)$. There was a significant $(p<0.05)$ decrease in the weight of pancreas after the induction of diabetes compared with the non-diabetic control. Treatment with 200 and 400 $\mathrm{mg} / \mathrm{kg}$ bw. of the extract caused a significant $(p<0.05)$ increase in the weight of the pancreas compared with the diabetic-untreated control. Diabetes caused a significant $(p<0.05)$ increase in the weight of the liver $6.830( \pm 0.01)$, right kidney $0.810( \pm 0.07)$ and left kidney $0.630( \pm 0.01)$, compared with the weight of the liver $5.908( \pm 0.02)$, right kidney $0.548( \pm 0.03)$ and left kidney 0.468 ( \pm 0.05) of non-diabetic control (Table 2). It was noted that treatment with the standard drug and the graded doses of the extract significantly $(p<0.05)$ reduced the weight of the liver, right kidney and left kidney, bringing it close to normal compared with the diabetic-untreated control. From the results in Table 2, it is apparent that the right kidney weighed higher than the left kidney.

The mean $( \pm S D)$ of the weight of the heart for the groups were as follows: normal-non diabetic control was $0.672( \pm 0.07)$, untreated diabetic was 0.685 ( \pm 0.00$), 100 \mathrm{mg} / \mathrm{kg}$ metformin-treated was 0.496 ( \pm 0.08$), 100 \mathrm{mg} / \mathrm{kg}$ aqueous extract-treated was 0.443 ( \pm 0.02 ), $200 \mathrm{mg} / \mathrm{kg}$ aqueous extract-treated was $0.440( \pm 0.07)$ and $400 \mathrm{mg} / \mathrm{kg}$ bw. aqueous extract-treated rats was $0.455( \pm 0.02)$. The mean $( \pm$ $\mathrm{SD})$ of the weight of the brain for the groups were as follows: normal-non diabetic control was 1.510 ( \pm 0.08$)$, untreated diabetic was $1.480( \pm 0.09), 100$ $\mathrm{mg} / \mathrm{kg}$ metformin-treated was $1.510( \pm 0.01), 100$ $\mathrm{mg} / \mathrm{kg}$ aqueous extract-treated was $1.380( \pm 0.01)$, $200 \mathrm{mg} / \mathrm{kg}$ aqueous extract-treated was $1.380( \pm 0.08)$ and $400 \mathrm{mg} / \mathrm{kg}$ bw. aqueous extract-treated rats was $1.375( \pm 0.01)$.

The mean $( \pm S D)$ of the weight of the lungs for the groups were as follows: normal-non diabetic control was $1.536( \pm 0.08)$, untreated diabetic was 1.680
$( \pm 0.01), 100 \mathrm{mg} / \mathrm{kg}$ metformin-treated was $1.516( \pm$ $0.07), 100 \mathrm{mg} / \mathrm{kg}$ aqueous extract-treated was 1.443 $( \pm 0.02), 200 \mathrm{mg} / \mathrm{kg}$ aqueous extract-treated was $1.310( \pm 0.01)$ and $400 \mathrm{mg} / \mathrm{kg}$ bw. aqueous extracttreated was $1.375( \pm 0.01)$. Induction of diabetes did not cause any significant difference in the weight of the heart, brain and lungs, compared with the nondiabetic control (Table 2).

\section{Result of Hematological Analyses}

Diabetes upstaged the hematological parameters in all the groups induced. The mean $( \pm \mathrm{SD})$ of the white blood cell (WBC) count of the normal rats, untreateddiabetic, $100 \mathrm{mg} / \mathrm{kg}$ metformin-treated, $100 \mathrm{mg} / \mathrm{kg}$ aqueous extract-treated, $200 \mathrm{mg} / \mathrm{kg}$ aqueous extracttreated and $400 \mathrm{mg} / \mathrm{kg}$ aqueous extract-treated rats were $16.30( \pm 1.302), 21.75( \pm 2.475), 17.74( \pm$ $0.7635), 17.97( \pm 2.650), 18.17( \pm 2.996)$ and $17.35( \pm$ 1.448), respectively. Induction of diabetes increased the WBC count, although the observed increase was not statistically $(p>0.05)$ significant. Treatment with the extract and the standard drug reduced the WBC count of the test groups, reducing it to near normal (Table 3$)$. The mean $( \pm \mathrm{SD})$ of the hemoglobin concentration of the groups treated with $100 \mathrm{mg} / \mathrm{kg}$ metformin, $100 \mathrm{mg} / \mathrm{kg}$ aqueous extract, $200 \mathrm{mg} / \mathrm{kg}$ aqueous extract and $400 \mathrm{mg} / \mathrm{kg}$ aqueous extract was 15.18 ( \pm 0.795$), 13.88( \pm 0.32), 14.03( \pm 0.50)$ and 14.93 $( \pm 0.64)$, respectively; these were increased significantly $(p<0.05)$ compared with the hemoglobin concentration of the diabetic untreated control of 8.200 $( \pm 0.990)$. There was an increase in the hemoglobin concentration of the extract-treated groups compared with the diabetic-untreated control (Table 3). The mean $( \pm \mathrm{SD})$ of the packed cell volume (PCV) of the of the groups treated with $100 \mathrm{mg} / \mathrm{kg}$ metformin, $100 \mathrm{mg} / \mathrm{kg}$ aqueous extract, $200 \mathrm{mg} / \mathrm{kg}$ aqueous extract and $400 \mathrm{mg} / \mathrm{kg}$ aqueous extract was 45.58 ( \pm 2.425), $41.63( \pm 0.85), 42.20( \pm 1.60)$ and $44.83( \pm$ $1.92)$, respectively; these were increased significantly $(p<0.05)$ compared with the PCV of the diabetic untreated control of $25.30( \pm 3.25)$. There was a significant $(p<0.05)$ increase in the PCV of the test groups which were treated for 28 days compared with the diabetic-untreated control. The group that was treated with $400 \mathrm{mg} / \mathrm{kg}$ bw. of $A$. indica showed a better increase in their PCV compared with the other test groups. The observed increase in the red blood cell (RBC) count of the test groups was not significant ( $p$ $<0.05)$ when compared with the diabetic untreated control. 
Table 1: The effect of treatment with different doses of aqueous extract of $A$. indica leaves on the body weight expressed mean \pm SD

\begin{tabular}{|c|c|c|c|c|c|c|}
\hline Time (Days) & Normal Rats & $\begin{array}{l}\text { Untreated } \\
\text { Diabetic }\end{array}$ & $\begin{array}{c}100 \mathrm{mg} / \mathrm{kg} \\
\text { Metformin }\end{array}$ & $\begin{array}{c}100 \mathrm{mg} / \mathrm{kg} \\
\text { Aqueous } \\
\text { Extract }\end{array}$ & $\begin{array}{c}200 \mathrm{mg} / \mathrm{kg} \\
\text { Aqueous } \\
\text { Extract }\end{array}$ & $\begin{array}{c}400 \mathrm{mg} / \mathrm{kg} \\
\text { Aqueous } \\
\text { Extract }\end{array}$ \\
\hline Initial weight & $137.4 \pm 0.894$ & $136.8 \pm 1.789$ & $133.6 \pm 2.510$ & $126.8 \pm 3.114$ & $126.2 \pm 1.304$ & $128.2 \pm 0.8367$ \\
\hline Day 0 & $141.3 \pm 2.060$ & $113.7 \pm 3.03^{a}$ & $118.3 \pm 4.21^{a}$ & $115.4 \pm 2.70^{a}$ & $114.9 \pm 3.03^{a}$ & $110.8 \pm 5.72^{a}$ \\
\hline Day 7 & $145.8 \pm 2.168$ & $115.3 \pm 7.37^{a}$ & $123.6 \pm 3.97^{a}$ & $117.8 \pm 4.11^{a}$ & $117.5 \pm 5.26^{a}$ & $116.5 \pm 7.72^{a}$ \\
\hline Day 14 & $155.0 \pm 4.062$ & $110.5 \pm 3.53^{a}$ & $122.8 \pm 1.92^{a}$ & $125.0 \pm 1.0^{a d}$ & $125.7 \pm 2.3^{a d}$ & $125.8 \pm 2.9^{a d}$ \\
\hline Day 21 & $164.4 \pm 4.220$ & $120.0 \pm 4.24^{a}$ & $131.8 \pm 4.55^{a}$ & $126.7 \pm 1.52^{a}$ & $125.7 \pm 2.30^{a}$ & $125.8 \pm 2.98^{a}$ \\
\hline Day 28 & $176.8 \pm 7.259$ & $126.5 \pm 4.95^{a}$ & $137.8 \pm 2.49^{a}$ & $129.0 \pm 2.64^{a}$ & $130.0 \pm 2.6^{a d}$ & $134.0 \pm 3.8^{a d}$ \\
\hline
\end{tabular}

a significant reduction with respect to normal control;

bsignificant increase with respect to normal control;

c significant reduction with respect to diabetic untreated control;

d significant increase with respect to diabetic untreated control.

Table 2: The effect of treatment with different doses of aqueous extract of $A$. indica leaves on the organ (pancreas, liver, right kidney, left kidney, heart, brain and lungs) weight expressed as mean \pm SD

\begin{tabular}{|c|c|c|c|c|c|c|}
\hline Organs & $\begin{array}{l}\text { Normal } \\
\text { (Non } \\
\text { diabetic) }\end{array}$ & $\begin{array}{l}\text { Untreated } \\
\text { Diabetic }\end{array}$ & $\begin{array}{l}100 \mathrm{mg} / \mathrm{kg} \\
\text { Metformin }\end{array}$ & $\begin{array}{c}100 \mathrm{mg} / \mathrm{kg} \\
\text { Aqueous } \\
\text { Extract }\end{array}$ & $\begin{array}{c}200 \mathrm{mg} / \mathrm{kg} \\
\text { Aqueous } \\
\text { Extract }\end{array}$ & $\begin{array}{c}400 \mathrm{mg} / \mathrm{kg} \\
\text { Aqueous } \\
\text { Extract }\end{array}$ \\
\hline Pancreas & $1.316 \pm 0.03$ & $0.815 \pm 0.04^{a}$ & $1.114 \pm 0.05$ & $1.147 \pm 0.08$ & $1.103 \pm 0.01^{d}$ & $1.178 \pm 0.01^{d}$ \\
\hline Liver & $5.908 \pm 0.02$ & $6.830 \pm 0.01^{b}$ & $\begin{array}{c}5.408 \pm \\
0.02^{c}\end{array}$ & $\begin{array}{c}5.140 \pm \\
0.02^{c}\end{array}$ & $5.377 \pm 0.04^{c}$ & $5.202 \pm 0.02^{c}$ \\
\hline Right Kidney & $0.548 \pm 0.03$ & $0.810 \pm 0.07^{b}$ & $\begin{array}{c}0.558 \pm \\
0.08^{c}\end{array}$ & $\begin{array}{c}0.590 \pm \\
0.04^{c}\end{array}$ & $0.563 \pm 0.04^{c}$ & $0.563 \pm 0.03^{c}$ \\
\hline Left Kidney & $0.468 \pm 0.05$ & $0.630 \pm 0.01^{b}$ & $\begin{array}{c}0.522 \pm \\
0.02^{c}\end{array}$ & $\begin{array}{c}0.563 \pm \\
0.01^{c}\end{array}$ & $0.560 \pm 0.01^{c}$ & $0.520 \pm 0.06^{c}$ \\
\hline Heart & $0.672 \pm 0.07$ & $0.685 \pm 0.00$ & $0.496 \pm 0.08$ & $0.443 \pm 0.02$ & $0.440 \pm 0.07$ & $0.455 \pm 0.02$ \\
\hline Brain & $1.510 \pm 0.08$ & $1.480 \pm 0.09$ & $1.510 \pm 0.01$ & $1.380 \pm 0.01$ & $1.380 \pm 0.08$ & $1.370 \pm 0.01$ \\
\hline Lungs & $1.536 \pm 0.08$ & $1.680 \pm 0.01$ & $1.516 \pm 0.07$ & $1.443 \pm 0.02$ & $1.310 \pm 0.01$ & $1.375 \pm 0.01$ \\
\hline
\end{tabular}

The mean $( \pm S D)$ of the platelet count of the normal control, untreated-diabetic, $100 \mathrm{mg} / \mathrm{kg}$ metformintreated, $100 \mathrm{mg} / \mathrm{kg}$ aqueous extract-treated, 200 $\mathrm{mg} / \mathrm{kg}$ aqueous extract-treated and $400 \mathrm{mg} / \mathrm{kg}$ aqueous extract-treated rats were 405.4 ( \pm 32.54$), 200.5$ ( \pm 83.3$), 369.4( \pm 34.2), 246.0$ ( \pm 69$), 262.3( \pm 46)$ and $384.0( \pm 75.8)$, respectively. There was a significant $(p<0.05)$ increase in the platelet count of groups treated with the standard drug and the extract, compared with the diabetic untreated control.

\section{Results of the Lipid Profile}

Induction of diabetes with streptozotocin caused a significant $(p<0.05)$ increase in the TCH, LDL-c, TG and VLDL-c of the diabetic-untreated control compared with the normal non-diabetic control (Table 4). The mean $( \pm \mathrm{SD})$ of the total cholesterol $(\mathrm{TCH})$ of the groups treated with $100 \mathrm{mg} / \mathrm{kg}$ metformin, $100 \mathrm{mg} / \mathrm{kg}$ aqueous extract, $200 \mathrm{mg} / \mathrm{kg}$ aqueous extract and 400 $\mathrm{mg} / \mathrm{kg}$ aqueous extract were $79.72( \pm 3.70), 77.03( \pm$ 1.79), $74.53( \pm 6.73)$ and $72.39( \pm 3.21)$, respectively; these decreased significantly $(p<0.05)$ compared with the TCH of the diabetic untreated control of 93.88 ( \pm 6.04). The total cholesterol concentration of the group 
Table 3: The effect of treatment with different doses of aqueous extract of $A$. indica leaves on the haematological parameters expressed as mean \pm SD

\begin{tabular}{|c|c|c|c|c|c|c|}
\hline $\begin{array}{l}\text { Haematologi- } \\
\text { cal } \\
\text { Parameters }\end{array}$ & $\begin{array}{l}\text { Normal } \\
\text { (Non- } \\
\text { diabetic) }\end{array}$ & $\begin{array}{c}\text { Diabtetic } \\
\text { Untreated } \\
\text { rats }\end{array}$ & $\begin{array}{l}100 \mathrm{mg} / \mathrm{kg} \\
\text { Metformin }\end{array}$ & $\begin{array}{c}100 \mathrm{mg} / \mathrm{kg} \\
\text { Aqueous } \\
\text { Extract }\end{array}$ & $\begin{array}{c}200 \mathrm{mg} / \mathrm{kg} \\
\text { Aqueous } \\
\text { Extract }\end{array}$ & $\begin{array}{c}400 \text { mg/kg } \\
\text { Aqueous } \\
\text { Extract }\end{array}$ \\
\hline $\mathrm{WBC}\left(\mathrm{x} 10^{9} / \mathrm{L}\right)$ & $\begin{array}{c}16.30 \pm \\
1.302\end{array}$ & $\begin{array}{c}21.75 \pm \\
2.475\end{array}$ & $\begin{array}{c}17.74 \pm \\
0.7635\end{array}$ & $17.97 \pm 2.650$ & $18.17 \pm 2.996$ & $17.35 \pm 1.448$ \\
\hline $\operatorname{HGB}(\mathrm{g} / \mathrm{dl})$ & $\begin{array}{c}11.78 \pm \\
0.3962\end{array}$ & $\begin{array}{c}8.200 \pm \\
0.990\end{array}$ & $\begin{array}{c}15.18 \pm \\
0.795^{d}\end{array}$ & $13.88 \pm 0.32^{d}$ & $14.03 \pm 0.50^{d}$ & $14.93 \pm 0.64^{d}$ \\
\hline PCV (\%) & $\begin{array}{c}40.52 \pm \\
2.213\end{array}$ & $\begin{array}{c}25.30 \pm \\
3.25^{a}\end{array}$ & $\begin{array}{c}45.58 \pm \\
2.425^{d}\end{array}$ & $41.63 \pm 0.85^{d}$ & $42.20 \pm 1.60^{d}$ & $44.83 \pm 1.92^{d}$ \\
\hline $\mathrm{RBC}\left(\mathrm{x} 10^{12} / \mathrm{L}\right)$ & $\begin{array}{c}7.652 \pm \\
0.1865\end{array}$ & $\begin{array}{c}5.515 \pm \\
0.149\end{array}$ & $\begin{array}{c}7.422 \pm \\
0.3920\end{array}$ & $6.730 \pm 0.418$ & $6.697 \pm 0.792$ & $7.275 \pm 0.249$ \\
\hline $\begin{array}{l}\text { Platelets } \\
\left(\mathrm{x} 10^{9} / \mathrm{L}\right)\end{array}$ & $\begin{array}{c}405.4 \pm \\
32.54\end{array}$ & $\begin{array}{c}200.5 \pm \\
83.3^{a}\end{array}$ & $\begin{array}{c}369.4 \pm \\
34.2^{d}\end{array}$ & $246.0 \pm 69^{a d}$ & $262.3 \pm 46^{a d}$ & $384.0 \pm 75.8^{d}$ \\
\hline
\end{tabular}

a significant reduction with respect to normal control;

b significant increase with respect to normal control;

csignificant reduction with respect to diabetic untreated control;

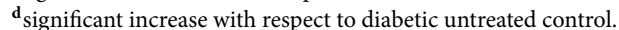

treated with $400 \mathrm{mg} / \mathrm{kg}$ bw. was $72.39( \pm 3.21)$, which was very close to that of the normal-non diabetic control of $70.01( \pm 5.941)$.

The mean $( \pm \mathrm{SD})$ of the high density lipoprotein cholesterol (HDL-c) of the groups treated with 100 $\mathrm{mg} / \mathrm{kg}$ metformin, $100 \mathrm{mg} / \mathrm{kg}$ aqueous extract, 200 $\mathrm{mg} / \mathrm{kg}$ aqueous extract and $400 \mathrm{mg} / \mathrm{kg}$ aqueous extract were 40.89 ( \pm 5.38$), 38.53( \pm 1.94), 40.40( \pm$ $5.73)$ and $46.54( \pm 2.05)$, respectively; these increased significantly $(p<0.05)$ compared with the HDL-c of the diabetic untreated control of 29.79 ( \pm 1.654). There was a significant $(p<0.05)$ increase in the HDL cholesterol concentration of all the extract-treated groups compared with the diabetic-untreated control. However, the increase was dose-dependent and was observed to be higher in the group that was treated with $400 \mathrm{mg} / \mathrm{kg}$ bw. of aqueous extract of $A$. indica. There was a significant $(p<0.05)$ decrease in the lowdensity lipoprotein-cholesterol (LDL-c) of the group treated with $400 \mathrm{mg} / \mathrm{kg}$ bw., which was $7.400( \pm 4.54)$, compared to that of the diabetic untreated control, which was 26.12 ( \pm 6.30$)$. The observed LDL-c of the group administered with $400 \mathrm{mg} / \mathrm{kg}$ bw. was 7.400 ( \pm 4.54 ), which is very close to the value recorded for the normal non-diabetic control of $5.386( \pm 2.685)$.

The mean $( \pm \mathrm{SD})$ of the triglyceride (TG) concentration of the groups treated with $100 \mathrm{mg} / \mathrm{kg}$ metformin, $100 \mathrm{mg} / \mathrm{kg}$ aqueous extract, $200 \mathrm{mg} / \mathrm{kg}$ aqueous extract and $400 \mathrm{mg} / \mathrm{kg}$ aqueous extract were 104.5 ( \pm 11$), 95.05$ ( \pm 1.39$), 96.45( \pm 5.95)$ and 92.27 $( \pm 7.00)$, respectively; these decreased significantly $(p<0.05)$ compared with the TG concentration of the diabetic untreated control of $189.9( \pm 9.54)$. The very low-density lipoprotein-cholesterol (VLDL-c) of the group treated with $100 \mathrm{mg} / \mathrm{kg}$ and $400 \mathrm{mg} / \mathrm{kg}$ bw. were $19.01( \pm 0.28)$ and $18.46( \pm 1.40)$, respectively, and those of the normal non-diabetic control and diabetic untreated control were $16.74( \pm 0.601)$ and $37.97( \pm 1.90)$, respectively. The values of the VLDL-c recorded for the test groups were close to that recorded for the normal non-diabetic control.

\section{Result of the Histopathological Analysis}

Group A (normal non-diabetic control) showed normal pancreas tissue. Group B (the diabetic untreated control) showed features of insulitis as evidenced by focal aggregates of Chronic Inflammatory Cells (CIC). These can cause inflammatory infiltration of the islets of Langerhans. The infiltrate classically consists of cytotoxic $\mathrm{T}$ cells, macrophages, $\mathrm{T}$ helper cells and B cells. Group C (the standard drug-100 mg/kg bw. metformin-treated group) showed centroacinar cells which are inconspicuous small cells with minimal cytoplasm and oval nuclei. A large Congested Vascular Channel (CVC) was seen running through the lobular formation of the acini. Group F (the group treated with $400 \mathrm{mg} / \mathrm{kg}$ bw. extract) showed Compact Islets (CI) consisting of round to oval, generally circumscribed collections of endocrine cells.

Group A (the normal non-diabetic control) showed normal liver tissue. Group B (the diabetic untreated control) showed hypoxic injury as evidenced by foci of micro and Macrovesicular Steatosis (MS). The central vein shows Vascular Congestion (VC). This is 
Table 4: The effect of treatment with different doses of aqueous extract of $A$. indica leaves on lipid profile expressed as mean \pm SD

\begin{tabular}{|c|c|c|c|c|c|c|}
\hline $\begin{array}{l}\text { Lipid Pro- } \\
\text { file (mg/dl) }\end{array}$ & $\begin{array}{l}\text { Normal } \\
\text { (Non- } \\
\text { diabetic) }\end{array}$ & $\begin{array}{c}\text { Diabetic } \\
\text { Untreated } \\
\text { Rats }\end{array}$ & $\begin{array}{l}100 \mathrm{mg} / \mathrm{kg} \\
\text { Metformin }\end{array}$ & $\begin{array}{c}100 \mathrm{mg} / \mathrm{kg} \\
\text { Aqueous } \\
\text { Extract }\end{array}$ & $\begin{array}{c}200 \mathrm{mg} / \mathrm{kg} \\
\text { Aqueous } \\
\text { Extract }\end{array}$ & $\begin{array}{c}400 \mathrm{mg} / \mathrm{kg} \\
\text { Aqueous } \\
\text { Extract }\end{array}$ \\
\hline $\mathrm{TCH}$ & $70.01 \pm 5.941$ & $\begin{array}{c}93.88 \pm \\
6.04^{b}\end{array}$ & $\begin{array}{c}79.72 \pm \\
3.7^{b c}\end{array}$ & $77.03 \pm 1.79^{c}$ & $\begin{array}{c}74.53 \pm \\
6.73^{c}\end{array}$ & $72.39 \pm 3.21^{c}$ \\
\hline HDL-c & $49.58 \pm 6.313$ & $\begin{array}{c}29.79 \pm \\
1.654^{a}\end{array}$ & $\begin{array}{c}40.89 \pm \\
5.38^{d}\end{array}$ & $38.53 \pm 1.94^{d}$ & $\begin{array}{c}40.40 \pm \\
5.73^{d}\end{array}$ & $46.54 \pm 2.05^{d}$ \\
\hline LDL-c & $5.386 \pm 2.685$ & $\begin{array}{c}26.12 \pm \\
6.30^{b}\end{array}$ & $\begin{array}{c}17.88 \pm \\
9.64^{b}\end{array}$ & $19.50 \pm 3.28^{b}$ & $\begin{array}{c}14.77 \pm \\
13.3^{b}\end{array}$ & $7.400 \pm 4.54^{c}$ \\
\hline TG & $83.71 \pm 3.018$ & $\begin{array}{c}189.9 \pm \\
9.54^{b}\end{array}$ & $104.5 \pm 11^{b c}$ & $95.05 \pm 1.39^{c}$ & $\begin{array}{c}96.45 \pm \\
5.95^{c}\end{array}$ & $92.27 \pm 7.00^{c}$ \\
\hline VLDL-c & $16.74 \pm 0.601$ & $\begin{array}{c}37.97 \pm \\
1.90^{b}\end{array}$ & $\begin{array}{c}20.94 \pm \\
2.2^{b c}\end{array}$ & $19.01 \pm 0.28^{c}$ & $\begin{array}{c}19.29 \pm \\
1.190\end{array}$ & $18.46 \pm 1.40^{c}$ \\
\hline
\end{tabular}

${ }^{\text {a }}$ significant reduction with respect to normal control,

b significant increase with respect to normal control;

c significant reduction with respect to diabetic untreated control;

d significant increase with respect to diabetic untreated control.

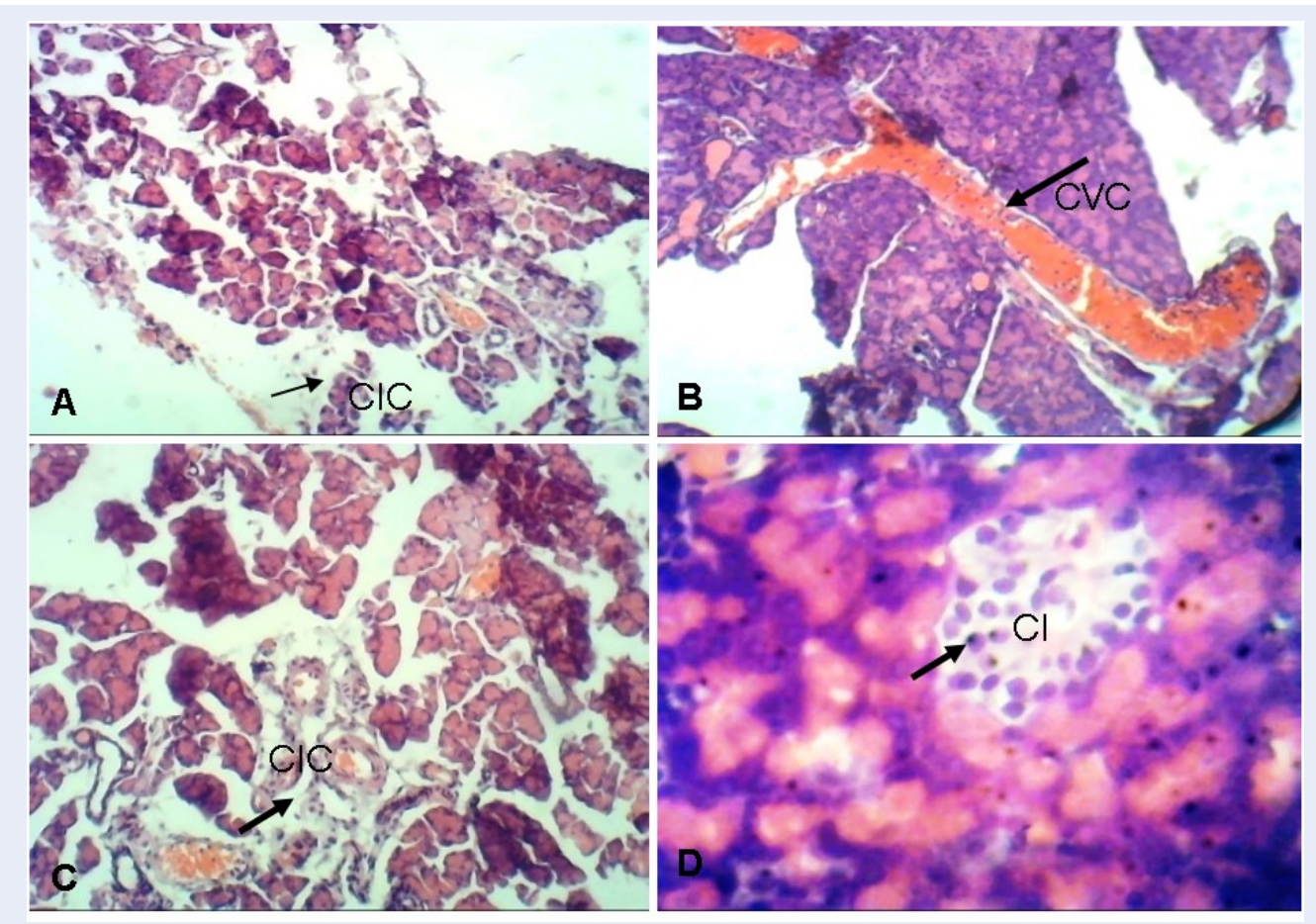

Figure 1: Photomicrograph of pancreatic tissue (magnification x10). A, Normal non-diabetic control. B, Diabetic-untreated. C, $100 \mathrm{mg} / \mathrm{kg}$ bw.Metformin treatment. F, $400 \mathrm{mg} / \mathrm{kg}$ bw. aqueous extract of $A$. indica treatment. 

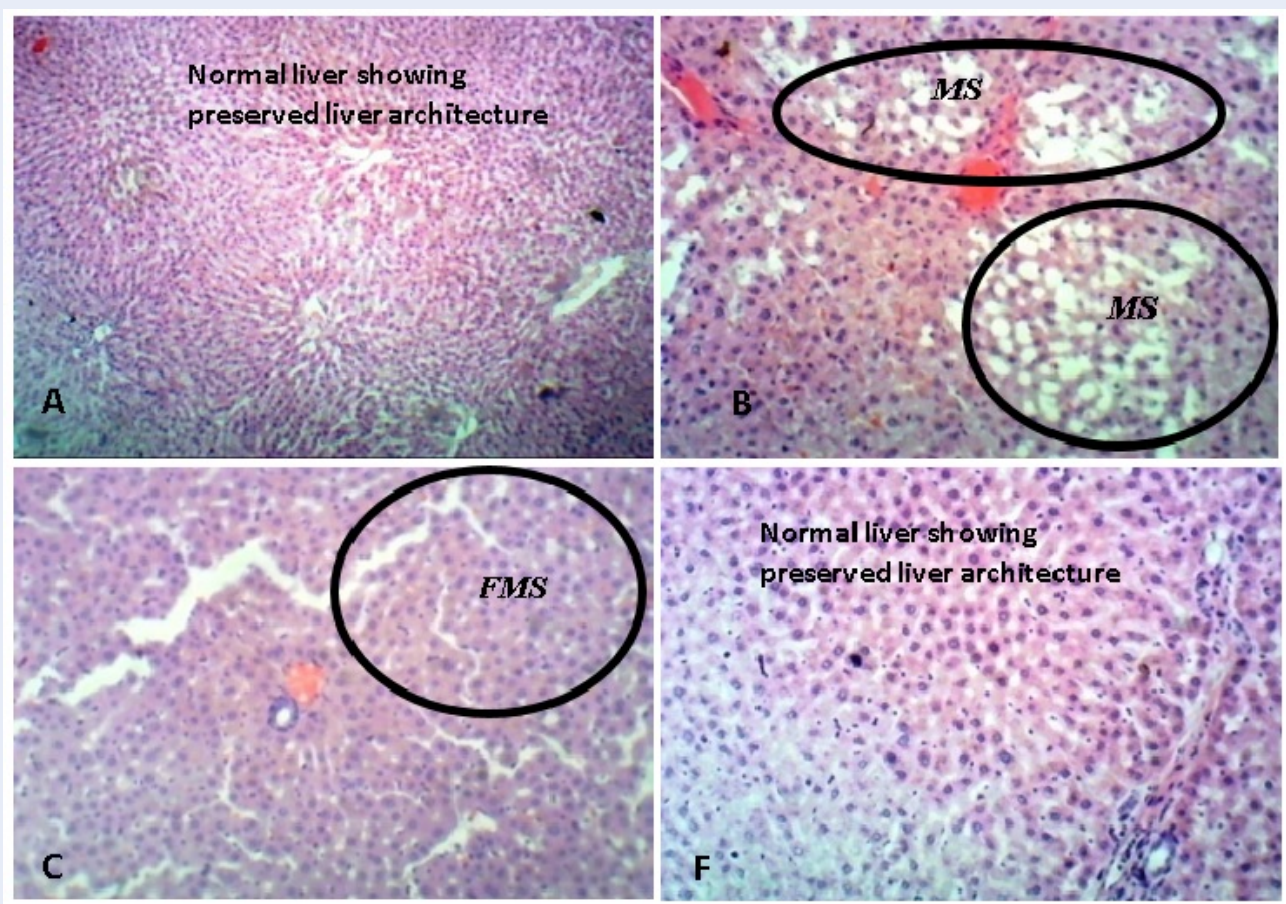

Figure 2: Photomicrograph of liver tissue (magnificationx10). A, Normal non-diabetic control. B, Diabeticuntreated. C,100 mg/kg bw. Metformin treatment. F, $400 \mathrm{mg} / \mathrm{kg}$ bw. aqueous extract of $A$. indica treatment.

the major cause of liver injury during transplantation. Group C (the standard drug-100 mg/kg bw. metformin-treated group) showed liver tissues with Focal Mild Steatohepatitis (FMS). The implication of this is serious fatty liver disease if not diagnosed early and treated. Group F (the group treated with 400 $\mathrm{mg} / \mathrm{kg}$ bw. extract) shows normal liver tissue.

Group A (normal non-diabetic control) showed normal kidney tissue. Group B (diabetic untreated control) showed Focal Interstitial Nephritis (FIN) with normal glomeruli, tubules and vascular channels. Interstitial nephritis is a kidney condition characterized by swelling in between the kidney tubules. Swelling of these tubules can cause a number of kidney symptoms that range from mild to severe conditions. Group C (standard drug-100mg/kg bw. metformintreated group) showed normal glomerular on light microscopy. Group F (treated with $400 \mathrm{mg} / \mathrm{kg}$ bw. extract) showed normal kidney tissue.

Group A (normal non-diabetic control) showed normal heart tissue. Group B (diabetic untreated control) showed lung tissue displaying Fat Embolism (FE) that is partly attached to the vascular wall. Fat embolism causes obstruction of the blood flow completely. It can also cause endothelial damage and respiratory failure. Group C (standard drug-100 mg/kg bw. metformin-treated group) showed myocardium of the heart which appeared normal. Group F (treated with $400 \mathrm{mg} / \mathrm{kg}$ bw. extract) showed normal myocardium with Focal Hemorrhage (FH), which causes hemorrhagic stroke where bleeding occurs directly into the brain.

Group A (normal non-diabetic control) showed normal cerebellum tissue. Group B (diabetic untreated control) showed evidence of Cerebral Hypoxia $(\mathrm{CH})$ and acute ischemic injury which causes increased eosinophilia of neurons as evidence of shrinkage, creating vacuoles around the neurons. Group C (standard drug-100 mg/kg bw. metformin-treated group) showed normal brain with normal villi lining the third ventricle. Group F (treated with $400 \mathrm{mg} / \mathrm{kg}$ bw. extract) showed normal brain tissue.

Group A (normal non-diabetic control) showed normal lung tissue. Group B (diabetic-untreated control) showed lungs with features of Interstitial Pneumonia (IP) with intense infiltration of the stroma by lymphoid cells, forming follicles with germinal centers. Group C (standard drug-100mg/kg bw. metformintreated group) showed lung with evidence of diffuse Interstitial Pneumonia (IP), which causes damage to the interstitium. The interstitium provides support to the lungs' microscopic air sacs (alveoli). Group F 

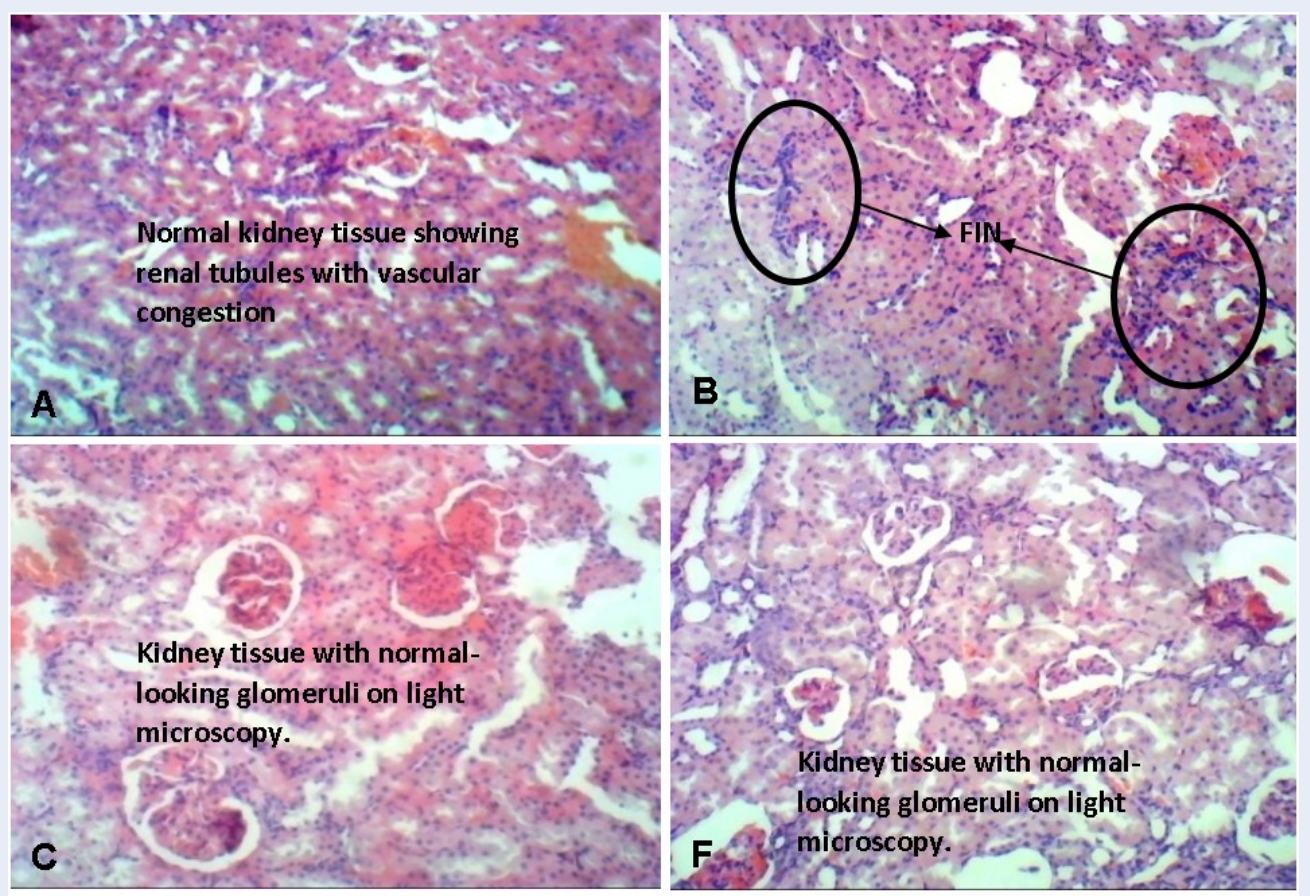

Figure 3: Photomicrographs of kidney tissue (magnification x10). A, Normal non-diabetic control. B, Diabetic untreated. $\mathbf{C}, 100 \mathrm{mg} / \mathrm{kg}$ bw. Metformin treatment. F, $400 \mathrm{mg} / \mathrm{kg}$ bw. aqueous extract of $A$. indica treatment.

(treated with $400 \mathrm{mg} / \mathrm{kg}$ bw. extract) showed evidence of IP. Interstitial lung disease leads to thickening of the supporting tissue around the air sacs rather than the air sacs themselves.

\section{DISCUSSION}

The use of $A$. indica leaves in traditional medicine practice for numerous health conditions, including prevention and treatment of diabetes, is gaining full acceptance within the local communities in Nigeria. Although its efficacy has not been sufficiently demonstrated, its modulatory effects on essential biochemical parameters and organ-system functions have yet to be fully established scientifically. Streptozotocin is used as an agent to induce diabetes mellitus by selective cytotoxicity effect on pancreatic beta cells. Thus, it affects endogenous insulin release and increases blood glucose levels ${ }^{22}$.

Induction of diabetes caused a significant weight loss in the experimental animals. Oral treatment with the graded doses of the aqueous extract of $A$. indica restored the bodyweight of the experimental animals to near normal (Table 1). The loss in bodyweight of the diabetic-untreated rats agrees with the findings of Oyedemi et al. ${ }^{23}$, who observed a similar effect on diabetic animals induced with streptozotocin. This re- duction may be linked to the degradation of structural proteins and muscle wasting ${ }^{24}$. The results show that aqueous extract of $A$. indica possesses the ability to manage fasting blood glucose levels ${ }^{14}$, as well as increasing the bodyweight of streptozotocin-induced diabetic rats. Also, from our results, it has been observed that the aqueous extract of $A$. indica leaf modulates organ weight favorably towards recovery and better health (Table 2).

The results of the hematological analyses revealed that the hematological parameters in the diabeticuntreated rats were disrupted which could be due to the effects of streptozotocin on rapidly-dividing hemopoietic cells and suppression of hemopoiesis as a result of insulin deficiency caused by the selective destruction of the cells in the Islets of Langerhans of the pancreas. Administration of neem leaf extract had a positive modulatory effect on the essential hematologic indices of diabetic rats, showing significant $(p<0.05)$ increases in hemoglobin and packed cell volume compared with the normal non-diabetic and the diabetic-untreated rats. It also restored the RBC and PLT to near average reference values (Table 3 ). The WBC count was significantly $(p<0.05)$ increased in the diabetic-untreated rats compared with the groups treated with the extracts of neem leaf at different concentrations. These results are in line with the reports 

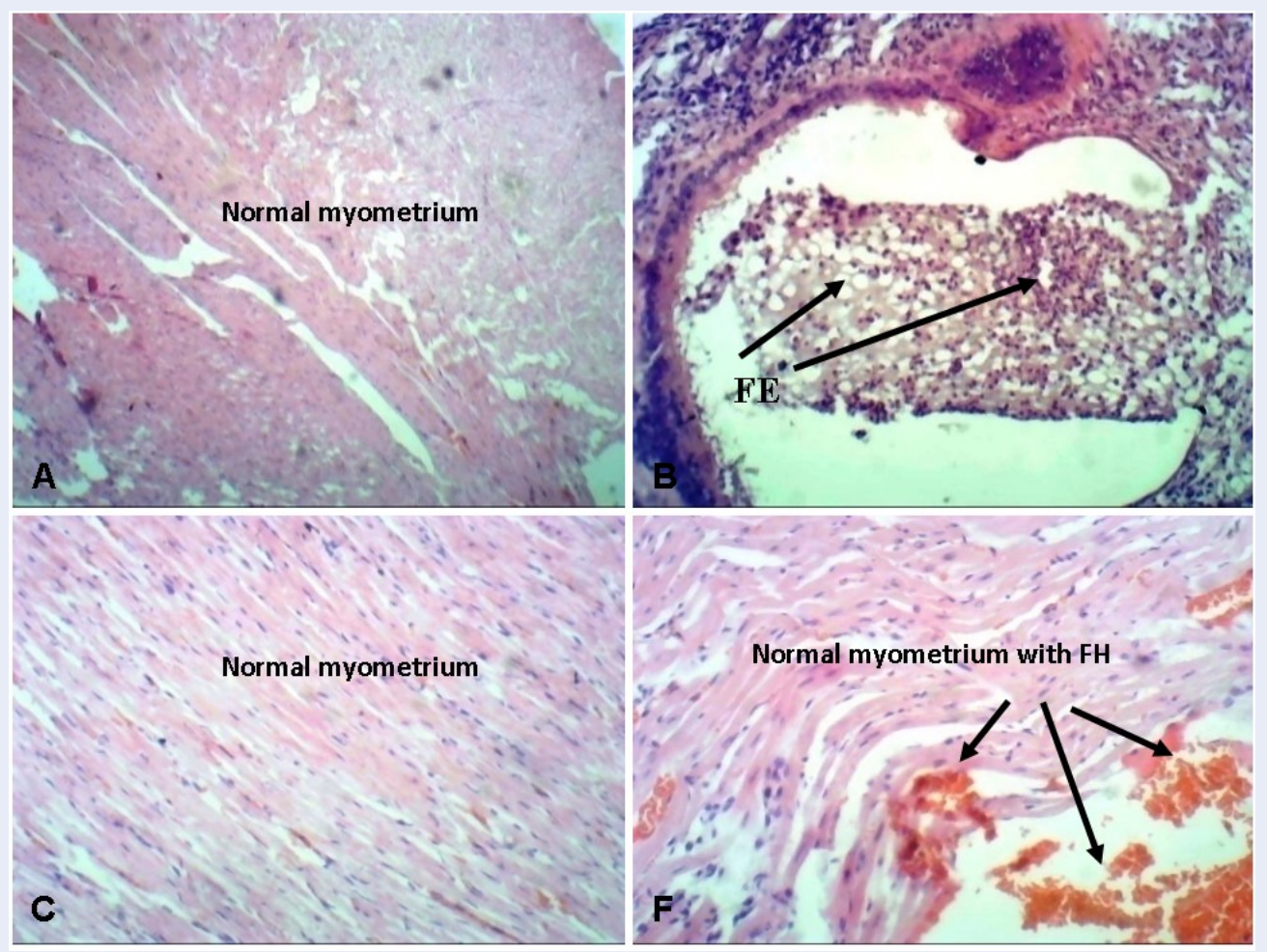

Figure 4: Photomicrographs of heart and pulmonary tissues (magnification x10). A,Normal non-diabetic control. B, Diabetic untreated. C,100 mg/kg bw. Metformin treatment. F, $400 \mathrm{mg} / \mathrm{kg}$ bw. aqueous extract of $A$. indica treatment.

by Inyang et al. ${ }^{25}$ on the effect of plant extracts on diabetic rats.

Diabetes upstaged the lipid profile of the laboratory animals, as was evident in the lipid profile of diabeticuntreated rats compared with normal non-diabetic rats (Table 4). It can be observed from the same table that the administration of neem leaf extract modulated the lipid profile even better than the standard antidiabetic drug metformin. The lipid profile analysis showed that the group of rats treated with extracts of neem leaf caused a significant $(p<0.05)$ decrease in TCH, LDL-c, TG and VLDL-c, compared with the diabetic-untreated rats. The rats treated with both extracts also showed a significant $(p<0.05)$ increase in the level of high-density lipoprotein compared with the diabetic-untreated rats. These results agree with the reports of Shravan and Kannappan, ${ }^{26}$, who noted that neem leaf extract reduced cholesterol and triglycerides in alloxan-induced diabetic rats. It is interesting to note that the modulation of $\mathrm{TCH}$ and LDL are dose-dependent.

The result of the pancreas of untreated diabetic rats revealed evidence of insulitis, as evidenced by a focal aggregate of chronic inflammatory cells (Figure 1).
The pancreas of the group treated with $400 \mathrm{mg} / \mathrm{kg}$ bw. of the aqueous extract was normal, revealing that the extract may be responsible for restoring the pancreas to normal. The liver of the untreated diabetic rats showed evidence of hypoxic injury with focal microand macro-vesicular steatosis (Figure 2). This can lead to severe fatty liver disease if not diagnosed early and treated. The liver of the aqueous extract-treated groups appeared normal with mild microvesicular steatosis and the kidney of the untreated diabetic rats showed focal interstitial nephritis. Interstitial nephritis is characterized by swelling in between the kidney tubules. The photomicrographs of the diabetic rats treated with the aqueous extract showed healthy kidney tissue (Figure 3).

Fat embolism caused obstruction of the capillary blood flow completely with associated endothelial damage and respiratory failure. This was seen in the heart of the diabetic untreated rats (Figure 4). The photomicrographs of the diabetic rats treated with the aqueous extract showed evidence of recovery from fat embolism. The brain of the untreated diabetic rats had a cerebral hypoxic, acute ischemic injury, increased eosinophilia of neurons (Figure 5). The 


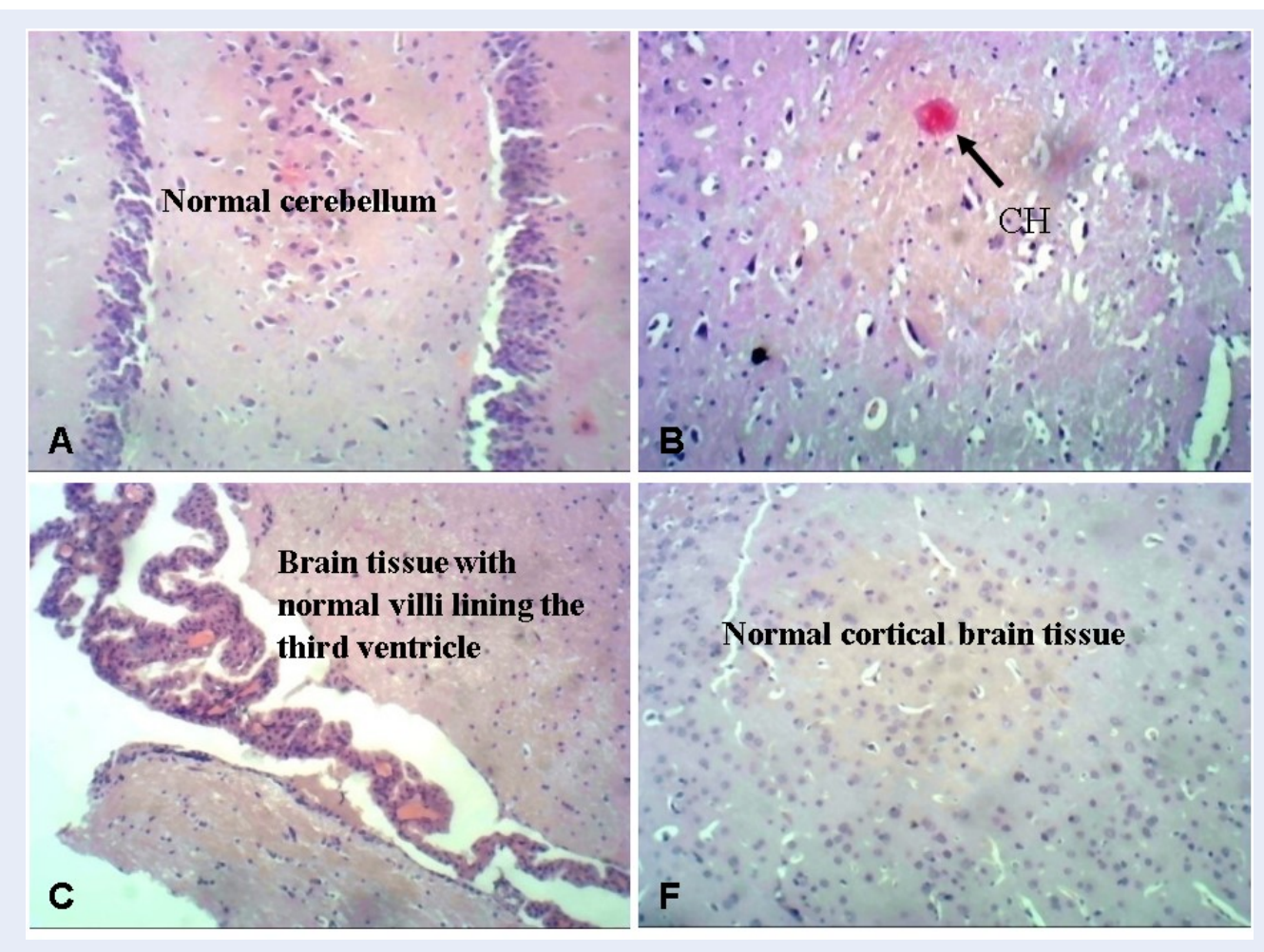

Figure 5: Photomicrographs of brain tissue (magnification x10). A, Normal non-diabetic control. B, Diabetic untreated. C, $100 \mathrm{mg} / \mathrm{kg}$ bw. Metformin treatment. F, $400 \mathrm{mg} / \mathrm{kg}$ bw. aqueous extract of $A$. indica treatment.

brain of the diabetic rats treated with the aqueous extracts appeared normal. The lung of the untreated diabetic rats had evidence of interstitial pneumonia (Figure 6). These abnormalities were observed to be mild in the photomicrographs of the lung of diabetic rats treated with the aqueous extract. These observations made from the histological studies of the organs of the diabetic-untreated rats could be responsible for the high mortality rate of the rats in the diabeticuntreated group compared with the group of rats that were treated with the aqueous extract and a standard drug.

The $A$. indica leaf extract caused a significant recovery from some of these observations made in the organs of the diabetic-untreated rats. The rats treated with the aqueous extract of $A$. indica leaf showed evidence of recovery from the abnormalities created by the induction of diabetes. This results are in accordance with those of the study reported by Baligar et al. ${ }^{27}$, which showed that treatment with $A$. indica leaf at the higher dose levels moderately restored the rat liver to normal. However, the extract did not wholly restore these abnormalities created by the induction of diabetes. There may be need for a treatment period of more than 28 days to ensure complete restoration of the complications and abnormalities caused by diabetes.

\section{CONCLUSION}

This study provides evidence of modulation of hematological parameters favorably as a result of the continuous administration of the aqueous extract of $A$. indica in streptozotocin-induced diabetic rats. The extract reduced total cholesterol, low-density lipoprotein cholesterol, triglycerides, very low-density lipoprotein-cholesterol and increased high-density lipoprotein cholesterol in streptozotocin-induced diabetic rats. Also, it is notable that the extract caused regeneration of the beta cells of the pancreas and reversed the deteriorative effects of diabetes in other essential organs studied. These results suggest that the aqueous extract of $A$. indica leaves will be a good regimen in the treatment and management of type 2 diabetes.

\section{ABBREVIATIONS}

bw.: body weight

CH: Cerebral Hypoxia

CI: Compact Islets

CIC: Chronic Inflammatory Cells 


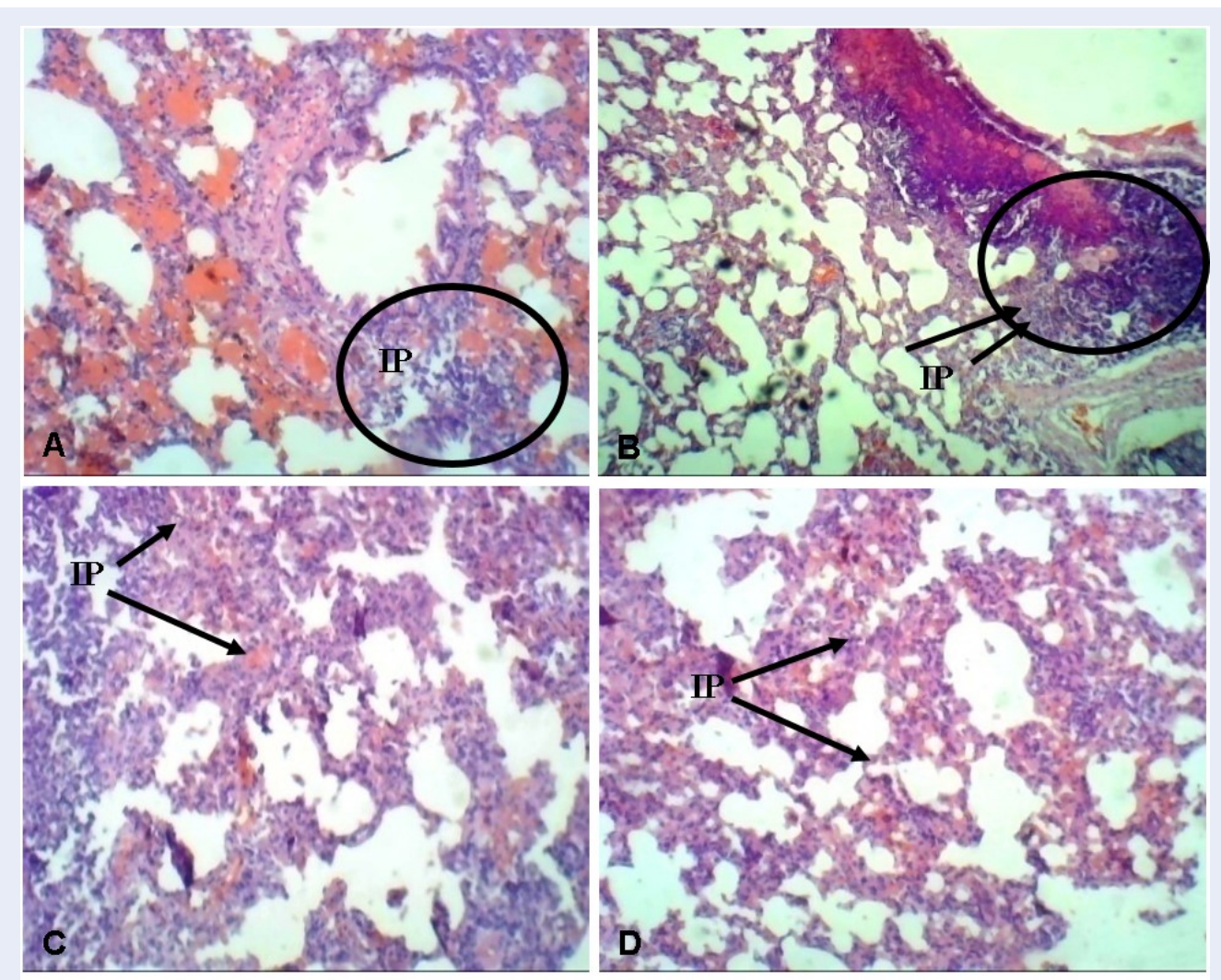

Figure 6: Photomicrographs of lung tissue (magnification x10). A, Normal non-diabeticcontrol. B, Diabetic untreated. C, $100 \mathrm{mg} / \mathrm{kg}$ bw. Metformin treatment. F, $400 \mathrm{mg} / \mathrm{kg}$ bw. aqueous extract of A.indica treatment.

CVC: Congested Vascular Channel

FE: Fat Embolism

FH: Focal Haemorrhage

FIN: Focal Interstitial Nephritis

FMS: Focal Mild Steatohepatosis

HDL-c: High-Density Lipoprotein cholesterol

HGB: Haemoglobin

IP: Interstitial Pneumonia

LDL-c: Low-Density Lipoprotein cholesterol

MS: Macrovesicular Steatosis

PCV: Packed Cell Volume

PLT: Platelets

RBC: Red Blood Cells

TCH: Total Cholesterol

TG: Triglycerides

VC: Vascular Congestion

VLDL-c: Very Low-Density Lipoprotein cholesterol WBC: White Blood Cells

\section{ACKNOWLEDGMENTS}

It is our pleasure to thank the manager of Chris Experimental Farm and Research Laboratory, Awka for providing the experimental animals used for the study. Our enormous thanks go to Dr. (Mrs.) B. O. Aziagba for assisting in the plant identification and authentification. Our unreserved gratitude goes to the Chief Laboratory Technologist, Mr. C. O. Anagonye of the Department of Applied Biochemistry, Faculty of Biosciences, Nnamdi Azikiwe University Awka, Anambra State, Nigeria, for his technical assistance.

\section{AUTHOR'S CONTRIBUTIONS}

Authors OCE and FCE designed the study, performed the statistical analysis and wrote the protocol. $\mathrm{Au}$ thors OCE and COO wrote the first draft of the manuscript. Authors OCE, DNO and MEO managed the literature searches and the analysis of the study. All authors read and approved the final manuscript.

\section{FUNDING}

No financial support or funding from any external source was used for this research. 


\section{AVAILABILITY OF DATA AND MATERIALS}

Data and materials used and/or analyzed during the current study are available from the corresponding author on reasonable request.

\section{ETHICS APPROVAL}

The study was carried out in strict compliance with the guide for the Institutional Animal Care and Use Committee (IACUC) of Nnamdi Azikiwe University, Awka, Nigeria in line with the recommendations of Animal Care and Use in Research, Education and Testing (ACURET).

\section{CONSENT FOR PUBLICATION}

Not applicable.

\section{COMPETING INTERESTS}

The authors declare that they have no competing interests.

\section{REFERENCES}

1. American Diabetes Association. Classification and Diagnosis of Diabetes. Diabetes care. 2017;40(1):S11-S24. Available from: https://doi.org/10.2337/dc17-S005PMid:27979889.

2. Liu S, Yu Z, Zhu H, Zhang W, Chen Y. In vitro $\alpha$-glucosidase inhibitory activity of isolated fractions from water extract of Qingzhuan dark tea. BMC Complementary and Alternative Medicine. 2016;16:378-386. PMID: 27681250. Available from: https://doi.org/10.1186/s12906-016-1361-0.

3. World Health Organization: Global report on diabetes. WHO library cataloging-in-publication data, Geneva 2016. 2016;.

4. Shiferaw BA, Ayalew JZ. Prevalence of Diabetes Mellitus and Its risk factors among individuals aged 15 years and above in Mizan-Aman Town, Southwest Ethiopia, 2016: A cross sectional study. International Journal of Endocrinology. 2018;2018:9317987. PMID: 29853887. Available from: https://doi.org/10.1155/2018/9317987.

5. International Diabetes Federation. Diabetes Atlas 6th ed International Diabetes Federation. 2013;.

6. Koul O, Isman MB, Ketkar CM. Properties and uses of neem, Azadirachtaindica. Canadian Journal of Botany. 1990;68:1-11. Available from: https://doi.org/10.1139/b90-001.

7. Barua CC, Talukdar A, Barua AG, Chakraborty A, Sarm RK, Bora RS. Evaluation of the wound healing activity of methanolic extract of Azadirachtaindica(Neem) and Tinosporacordifolia (Guduchi) in rats. PharmacologyOnline. 2010;1:70-77.

8. Biswas K, Chattopadhyay I, Banerjee R, Bandyopadhyay U. Biological activities and medicinal properties of neem (Azadirachtaindica). Current Science. 2002;82(11):1336-1345.

9. Dixit VP, Sinha R, Tank R. Effect of neem seed oil on the blood glucose concentration of normal and alloxan diabetic rats. Journal of Ethnopharcology. 1986;17:95-98. Available from: https://doi.org/10.1016/0378-8741(86)90076-0.

10. Ezeigwe OC, Ononamadu CJ, Enemchukwu BN, Umeoguaju UF, Okoro JC. Antidiabetic and Antidiabetogenic properties of the aqueous extracts of Azadirachtaindica leaves on alloxaninduced diabetic wistar rats. International Journal of Biosciences. 2015;7(2):116-126. Available from: https://doi.org/ $10.12692 / \mathrm{ijb} / 7.2 .116-126$.

11. Mishra AG, Sudeep P, Savita M, Akansha R, Arun M, Rakesh SA. Effect of Azadirachtaindica leaves on streptozotocin-induced diabetes mellitus and its associated complications. World Journal of Pharmaceutical Sciences. 2015;3:500-511.
12. Steiner G. Risk factors for macrovascular disease in type 2 diabetes: Classic lipid abnormalities. Diabetes Care. 1999;22(3):C6-C9.

13. Massing MW, Sueta CA, Chowdhury M, Biggs DP, Simpson RJ. Lipid management among coronary artery disease patients in diabetes mellitus or advanced age. American Journal of Cardiology. 2001;87:646-664. Available from: https://doi.org/10. 1016/S0002-9149(00)01447-8.

14. Ezeigwe OC, Ezennaya CF, Ifedilichukwu NH, Soronnadi VN, Chukwuemeka UV, Alaebo PO. Antidiabetic Property and Antioxidant Potentials of Aqueous Extract of Azadirachta indica Leaves in Streptozotocin-induced Diabetic Rats. Journal of Medicinal Plants Studies. 2019;7(6):18-23.

15. Ezeigwe OC, Ezeonu FC, Nnadi NN. Effect of aqueous extract of Azadirachtaindica leaf on some essential biochemical parameters of streptozotocin-induced diabetic rats. International Journal of Medical Science and Advanced Clinical Research. 2020;3(1):67-79. Available from: https://doi.org/10. 9734/ijbcrr/2019/v28i430157.

16. Zafar M, ul Hassan NSN. Effects of STZ-Induced diabetes on the relative weights of kidney, liver andpancreas in albino rats: a comparative study. International Journal of Morphology. 2010;28(1):135-142. Available from: https://doi.org/10.4067/ S0717-95022010000100019.

17. Eleazu CO, Iroaganachi M, Okafor PN, Ijeh II, Eleazu KC. Ameliorative Potentials of Ginger (Z. officinale Roscoe) on Relative Organ weights in streptozotocin-induced diabetic rats. International Journal of Biomedical Sciences. 2013;9(2):8290. PMID: 23971053. Available from: https://doi.org/10.1155/ 2013/160964.

18. Trinder $P$. Determination of glucose in blood using glucose oxidase with an alternative oxygen acceptor. Annals of Clinical Biochemistry. 1967;6:24-27. Available from: https://doi.org/ 10.1177/000456326900600108.

19. Tietze NW, Finley PR, Pruden EL. Clinical Guide to Laboratory Tests. 2nd Edition, WB Saunders, Philadelphia. 1990;p. 304306.

20. Friedewald WT, Levy RI, Fredrickson DS. Estimation of the concentration of low-density lipoprotein cholesterol in plasma, without use of preparative ultracentrifuge. Clinical Chemistry. 1972;18:499-502. PMID: 4337382. Available from: https: //doi.org/10.1093/clinchem/18.6.499.

21. Titford M. Progress in the development of microscopical techniques for diagnostic pathology. Journal of Histotechnology. 2009;32:9-19. Available from: https://doi.org/10.1179/his. 2009.32.1.9.

22. Nastaran JS. Antihyperglycaemia and antilipidaemic effect of Ziziphus vulgaris $L$ on streptozotocin induced diabetic adult male Wistar rats. Journal of Physiology and Pharmacology. 2011;47(1):219-223. PMID: 19960209. Available from: https: //doi.org/10.1007/s00592-009-0166-8.

23. Oyedemi SO, Yakubu MT, Afolayan AJ. Antidiabetic activities of aqueous leaves extract of Leonotisleonurus in streptozotocin induced diabetic rats. Journal of Medicinal Plant Research. 2011;5(1):119-125.

24. Shenoy AG, Ramesh KG. Improvement of insulin sensitivity by perindopril in spontaneously hypertensive and streptozotocin induced diabetic rats. Indian Journal of Pharmacology. 2002;34:156-164.

25. Inyang IR, Ogamba EN, Inerepamo O. Effect of 2.4 dichlorophenoxyacetic acid on some selected haematological and biochemical parameters in Clariasgariepinus. International Journal of Biochemistry. 2014;195:368 -373.

26. Shravan KM, Kannappan N. Invivo Antidiabetic Evaluation of A. indica Leaf Extract inAlloxan Induced Rats. Journal of Applied Pharmaceutical Science. 2011;7:100-105.

27. Baligar NS, Aladakatti RH, Ahmed M, Hiremath MB. Evaluation of Acute Toxicity of Neem Active Constituent, Nimbolide and its Hepatoprotective Activity against Acute Dose of Carbon Tetrachloride treated Albino Rats. International Journal of Pharmaceutical Sciences and Research. 2014;5(8):3455-3466. 